UDC: $616.155-002-074: 577.1$ 616.98-084:615.38

Stanković, i sar. Krvlju prenosive

bolesti.

NČ UM Halo 194. 2019;_25(3):

129-144.

Rad primljen: 14.04.2019

Prihvaćen: 12.12 .2019 .

\section{Korespodencija:}

Bratislav Stanković

Akademija strukovnih studija

Cara Dušana 254

11080 Zemun

Srbija

Mob.tel. 064/157-94-96

E-mail:

dr.bratislavstankovic@gmail.com

\section{ORIGINALNI RAD}

\section{ISPITIVANJE MARKERA KRVLJU PRENOSIVIH BOLESTI, ALGORITAMA TESTIRANJA I PREVENTIVNIH MERA}

\author{
Bratislav STANKOVIĆ ${ }^{1}$, Ljiljana GOJKOVIĆ-BUKARICA ${ }^{l}$, Marija TRIŠOVIĆ , \\ Milenko BUDIMČIĆ ${ }^{l}$, Žana GAJIĆ ${ }^{l}$, Vladan RISTIĆ
}

${ }^{1}$ Akademija strukovnih studija, Beograd; Visoka zdravstvena škola strukovnih studija u Beogradu, Zemun, Srbija. ${ }^{2}$ Stomatološki fakultet, Beograd, Srbija.

\begin{abstract}
SAŽETAK
Uvod/cilj Najčešće krvlju prenosive bolesti ili transfuzijske transmisivne infekcije (TTI) su hepatitis tipa B i C i virus humane imunodeficijencije (HIV). Brojnim testovima može se dokazati njihovo prisustvo u krvi indirektnim (prisustvo antitela - ELISA i CLIA) ili direktnim putem (prisustvo genoma virusa NAT PCR i LCR). Cilj rada je analiza testiranja na markere krvlju prenosivih bolesti kod trudnica, pacijenata koji se pripremaju za planirane hirurške procdure i osobe sa rizičnim ponašanjem na prisustvo virusa (HBs Ag, anti-HCV i anti-HIV) sprovedenog u Gradskom zavodu za javno zdravlje u Beogradu i upoznavanje sa preventivnim merama za njihovo suzbijanje.

Metod rada U dvogodišnjoj studiji testirano je 11.983 trudnica i 934 osoba sa rizičnim ponašanjem. Preliminarno testiranje na HBs Ag, antitela anti-HCV i anti-HIV, vršeno je ELISA testom treće generacije. Preliminarno pozitivni uzorci krvi ponovno su testirani istim testom iz novog uzorka, nakon 10-14 dana od utvrđene preliminarne pozitivnosti na ispitivane markere TTI. Kod ponovno pozitivnih uzoraka krvi rađen je potvrdni "Western Blot" test za određivanje antitela u humanom serumu ili plazmi, na markere TTI. Uzorci krvi pozitivni na potvrdnom testu na ispitivane markere TTI, prihvaćeni su kao potvrdno HBs Ag pozitivni, potvrdno anti-HCV reaktivni i potvrdno anti-HIV reaktivni.
\end{abstract}

Rezultati Od ukupno testiranih trudnica bilo je $152(1,27 \%)$ preliminarno reaktivnih, 38 potvrdno pozitivnih na HBsAg $(0,32 \%)$ i $114(0,95 \%)$ lažno reaktivnih na HBsAg; 123 $(1,03 \%)$ preliminarno reaktivnih na anti-HCV, 35 potvrdno pozitivnih trudnica na antitelo antiHCV $(0,29 \%)$ i $88(0,74 \%)$ lažno pozitivnih na HCV; i $15(0,13 \%)$ preliminarno reaktivnih, 5 trudnica potvrdno pozitivnih na antitelo anti-HIV $(0,04 \%)$ i $10(0,09 \%)$ lažno reaktivnih antiHIV. Od 934 testirane osobe sa rizičnim ponašanjem detektovano je $36(3,85 \%)$ preliminarno reaktivnih na HBs Ag, 28 (2,99\%) potvrdno pozitivnih na HbsAg i 8 (0,86\%) lažno reaktivnih HBsAg; $38(4,07 \%)$ preliminarno reaktivnih anti-HCV, $33(3,53 \%)$ potvrdno pozitivnih na anti-HCV i $5(0,54 \%)$ lažno reaktivnih na anti-HCV, kao i $10(1,07 \%)$ preliminarno anti-HIV reaktivnih, $9(0,96 \%)$ anti-HIV potvrdno pozitivnih i jedna $(0,11 \%)$ osoba lažno-reaktivno na anti-HIV sa rizičnim ponašanjem.

Zaključak Naše ispitivanje pokazuje veću prevalencu na HbsAg, anti-HCV i anti-HIV kod osoba sa rizičnim ponašanjem $u$ odnosu na trudnice, ako i veću razliku u nalazu lažno reaktivnih rezultata kod trudnica, u odnosu na osobe rizičnog ponašanja. Preventivne mere sastojale bi se u edukaciji stanovništva o putevima širenja krvlju prenosivih bolesti, njihovoj prevenciji, testiranju krvi i krvnih produkata testovima najnovije generacije i pravilnom izvođenju medicinskih intervencija uz poštovanje principa asepse i antisepse.

Ključne reči: markeri, krvlju prenosive bolesti, algoritmi, preventivne mere.

\section{Uvod}

Transfuzijom krvi i hemoprodukata (hemoterapija) mogu se preneti različiti virusi, bakterije $i$ paraziti koji se nalaze u krvi potencijalnih dobrovoljnih davalaca. U dostupnoj medicinskoj literaturi [1-6], opisane su različite bolesti i mikroorganizmi koji mogu biti preneti transfuzijom krvi/hemoprodukata, tzv. krvlju prenosive bolesti ili transfuzijski transmisivne infekcije (TTI). Ove bolesti pojedini autori [1-3], nazivaju i hematogene transmisivne bolesti. 
Virusni infektivni agensi koji su izazivači posttransfuzijskog hepatitisa su virusi hepatitisa tipa A (HAV), tipa B (HBV), tipa C (HCV), tipa D (HDV), tipa $\mathrm{E}$ (HEV), tipa F (HFV), tipa G (HGV) i virus parvo B19. Virus humane imunodeficijencije (HIV virus) i humani T-ćelijsko limfotropni virus (HTLVI/II) izazivaju teške infekcije kod anti-HIV pozitivnih bolesnika i sindrom stečene imunodeficijencije (AIDS); citomegalovirus izaziva citomegalovirozu (u literaturi nazvanana "bolest poljupca"); Epstein-Barrov virus i Humani herpes virus 6 uzrokuju hepatitis, pneumonitis, mijelopatiju, spastičku paraparezu i druge bolesti. Njihov epidemiološki značaj nije podjednak zbog različite učestalosti u različitim geografskim područjima, kao i različite učestalosti prelaska oboljenja u hronične oblike [1-6].

Najčešća oboljenja koja se prenose putem krvi izazvana su virusima HBV, HCV i HIV-a, ili bakterijom treponema palidaum (sifilis). Postoje brojni testovi kojima se dokazuje prisustvo virusa indirektnim putem (prisustvo antitela - ELISA I CLIA) ili direktnim putem (prisustvo genoma virusa NAT PCR i LCR) $[2,3]$.

Preventivne mere i postupci za smanjenje rizika od širenja TTI su bazirani na upotrebi pet glavnih strategija: 1) pravilan izbor dobrovoljnih davalaca krvi; 2) laboratorijsko skriningovanje jedinica krvi/ hemoprodukata; 3) inaktivacija virusa u krvi i hemoproduktima; 4) ograničavanje transfuzije krvi/ hemoprodukata kod bolesnika sa striktnim kliničkim indikacijama; 5) upotreba autologne transfuzije i drugih alternativa alogene transfuzije [1-5].

HBV je globalni zdravstveni problem [1]. Detekcija osoba inficiranih ovim virusima u grupi potencijalnih dobrovoljnih davalaca krvi, predstavlja osnovnu preventivnu meru kojom se danas možemo suprostaviti širenju virusnih oboljenja [6]. Davne 1947. godine, McCallum i saradnici su predložili klasifikaciju virusnih hepatitisa na A ("infektivni hepatitis") i B ("serumski hepatitis") [2,3,11,15]. Uprkos uvođenju testova za dijagnostikovanje ova dva tipa hepatitisa, nije bila retka pojava posttransfuzionog hepatitisa (PTH), kao i sporadično stečenog hepatitisa prouzrokovanog ne samo HAV-om ili HBV-om, nego i nekim drugim tipovima virusa. Zbog toga je Nacionalni Institut za zdravlje SAD predložio da virus hepatitis tipa nonA/nonB (NANBH) bude naziv za oboljenje prouzrokovano ovim tipovima virusa $[2,3,8,9]$. U vezi sa tim, ustanovljeno je da postoje enteralni i parenteralni tip NANBH. Uzročnik ente- ralnog NANBH je virus E (HEV), a parenteralnog hepatitisa je $\mathrm{HCV}[2,3,8-10]$.

U poslednjih petnaestak godina otkriveni su do tada nepoznati virusi i antitela protiv njih u krvi bolesnika i velikog broja dobrovoljnih davalaca krvi. Krvlju prenosive bolesti (TTI) brže se evidentiraju sistematskim praćenjem transfundovanih bolesnika (posebno onih koji su na hroničnom programu hemoterapije) i dobrovoljnih davalaca krvi, kao i usavršavanjem pretransfuzijskih testova za ispitivanje markera TTI. Zarazne bolesti koje se prenose preko krvi i/ili produkata od krvi mogu biti prouzrokovane virusima, bakterijama, ređe parazitima, a samo teoretski gljivicama. Pojedine studije $[2-5,9,16]$ sugerišu da se putem transfuzije mogu preneti i prioni, tj. infektivne čestice koje se sastoje od proteina bez nukleinske kiseline ("proteinaceous infections particles") a njihovu građa i opasnost od prenosa putem transfuzije trebalo bi detaljnije ispitati.

Prvi put, 1975. godine, hepatitis C je opisan kao posttransfuziona žutica, a 1989. godine kompletirana je struktura virona. HCV infekcija se prenosi parenteralno ili seksualnim putem, a tok bolesti je podmukao. Ovim virusom je inficirano preko $3 \%$ svetske populacije, a godišnje umre 250.000 ljudi. Inkubacija traje od 2 do 20 nedelja. Klinički se bolest primarno ispoljava kao akutna virusna infekcija. Međutim, u 20 do $50 \%$ bolesnika ispoljen je hronicitet, koji može dovesti do ciroze jetre ili hepatocelularnog karcinoma [2,3,16]. Ciroza jetre evidentirana je u $80 \%$ HCV-om zaraženih bolesnika, ali tek nakon inkubacije od 20 do 25 godina. Hepatocelularni karcinom može nastati u oko 5 do $10 \%$ zaraženih bolesnika nakon 25 do 30 godina inkubacije [16].

Replikacija virusa je na niskom nivou zbog čega direktna detekcija HCV-a u serumu ili tkivu zahteva visoku tehnologiju [NAT (PCR)-HCV testiranje]. Enzim imuno testiranje testovima treće generacije (Enzyme imuno assay - EIA) je indirektna serološka dijagnostika i predstavlja metod izbora. Nedostaci ovog testiranja su lažno pozitivni nalazi kod osoba koje su preležale infekciju i lažno negativni nalazi na početku infekcije (tzv. period "prozora" koji je kod HCV-a jako dug i iznosi oko 9 nedelja) [1-6, 8, $9,11,16]$.

Sedamdasetih godina prošlog veka, medicina se suočila sa potpuno novim infektivnim oboljenjima, kao što je "acquired immune deficiency syndrome" (AIDS) ili sindrom stečene imuno deficijencije (SIDA), čiji je uzročnik virus humane imunode- 
ficijencije-HIV [6]. HIV je izolovan iz ćelija inficiranog bolesnika 1983. godine (HIV-1), dok je 1986. godine izolovan i drugi tip HIV-a označen kao HIV-2, kao uzročnik iste bolesti. HIV-1 i HIV-2 su morfološki slični, s tim da je poslednji manje patogen. HIV pripada grupi humanih retrovirusa a porodici lentivirusa. Kompleksnost genoma lentivirusa je karakteristika koja ih izdvaja od ostalih retrovirusa. Tipovi HIV-a su definisani genomskom organizacijom, a podtipovi A, B, C, D, E, F, G, H i O su određeni izmenama $\mathrm{u}$ redosledu aminokiselina. HIV-u 1 pripada i podtipu O označen kao "outliers", jer se ne može klasifikovati ni u jednu grupu od do sada prepoznatih 8 podtipova [16-18]. Virusne čestice su okruglog oblika, veličine od 100-120 nm u prečniku i imaju veliki afinitet za $\mathrm{CD} 4^{+} \mathrm{T}$ - limfocite. Vezani HIV virusi za manje transmembranske proteine omogućuju, pošto se prethodno virus zakači za ćeliju, fuziju virusnog omotača sa ćelijskom membranom i ulazak unutrašnjeg sadržaja virusa HIV-a u ćeliju [2-6]. AIDS je po prvi put prepoznata kao nova bolest 1981. godine u SAD. Od tada se broj obolelih od HIV infekcije povećava eksponencijalnom brzinom. Prema podacima Svetske Zdravstvene Organizacije (SZO) od HIV-a u svetu boluje oko 33,2 miliona ljudi. Procena je da je prevalenca HIV-a u Srbiji i Crnoj Gori između 0,1 i $0,5 \%$ stanovništva, što znači da je inficirano oko 10.000 do 15.000 osoba [5-8]. Inkubacija AIDS-a traje od 2 do 5 godina. Evolucija bolesti je duga, ponekad je potrebno da prođe desetak godina od perioda infekcije do manifestacije bolesti. Rizične grupe su homoseksualci (70-75\%) i intravenski zavisnici $(2-15 \%)$, dok $1-4 \%$ čine hemofiličari i bolesnici koji su primili krv inficiranu HIV-om. Postoje osobe koje nazivamo "non progresor" koje ostaju zdrave bez promena u imunološkom sistemu više godina nakon primarne infekcije [5,8].

Primarna infekcija kod 40 do $70 \%$ bolesnika dovodi do sindroma sličnog mononukleozi (glavobolja, eritematozni raš, dijareja, gušobolja, generalizovana limfadenopatija). Laboratorijski nalazi pokazuju leukopeniju, anemiju, trombocitopeniju, atipične limfocite, povišenu aktivnost enzima jetre $i$ hipergamaglobulinemiju. Broj $\mathrm{CD}^{+}$limfocita opa$\mathrm{da}$, što utiče na promenu odnosa $\mathrm{CD} 4^{+} / \mathrm{CD}^{+}$u perifernoj krvi. Mogući mehanizmi smanjenja broja $\mathrm{CD}^{+}{ }^{+} \mathrm{T}$ - limfocita pri infekciji HIV-om su: direktni citopatogeni efekat, specifični imuni i autoimuni (molekularna mimikrija) odgovor, anergija i apoptoza. Sniženje broja $\mathrm{CD} 4^{+} \mathrm{T}$ - limfocita stvara uslove za oportunističke infekcije, neoplazije, encefalopatiju i progresivnu multifokalnu leukoencefalopatiju što dovodi do sve teže kliničke slike i do smrti bolesnika [2-6].

Detektabilni znaci infekcije koji se javljaju u krvi za vreme ili posle infekcije nazivaju se markerima infekcije. Klasifikacija rezultata testiranja je sledeća: 1) negativan/pozitivan određen statusom davaoca, 2) nereaktivan/reaktivan i 3) neodređen. Izbor adekvatnog preliminarnog testa u skriningu potencijalnih dobrovoljnih davalaca krvi zavisi od interpretacije rezultata i stepena pouzdanosti testa. Svi testirani potencijalni dobrovoljni davaoci krvi se svrstavaju u četiri grupe: 1) stvarno pozitivne; 2) lažno pozitivne; 3) lažno negativne i 4) stvarno negativne [1-4].

Tokom ranog perioda infekcije, detektuje se viremija u plazmi i prisustvo anti-HIV specifičnih antitela. Viremija se otkriva detektovanjem HIV RNK u plazmi pomoću tehnike PCR već 12. dana od inficiranja, a antitela kao specifičan marker infekcije 22. dana. Primenom testova prve generacije odobrene od strane "Agencija za hranu i lekove" SAD (FDA), 1985. godine, mogla su se detektovati antitela protiv HIV-a, 51.-55. dana od inficiranja, a uvođenjem testova druge i treće generacije (1992. god.), taj period je skraćen na 22 dana [19].

\section{Cilj rada}

Ciljevi ove studije su retrospektivna dvogodišnja analiza testiranja trudnica i osoba sa rizičnim ponašanjem na prisustvo virusa ( $\mathrm{HBs} \mathrm{Ag}$, antiHCV i anti-HIV) u Gradskom zavodu za javno zdravlje u Beogradu (GZZJZ), upoznavanje sa savremenim algoritmima testiranja na markere TTI, utvrđivanje prevalencije javljanja krvlju prenosivih bolesti u različitim populacijama ispitanika i poređenje dobijenih rezultata sa podacima iz dostupne literature.

\section{Metod rada}

U dvogodišnjem periodu (od 01.01.2017. do 31.12.2018.) testirano je 11.983 trudnica, 934 osobe sa rizičnim ponašanjem i 5.411 pacijenata koji se određeni za planiranu hiruršku proceduru. Struktura ispitivanih osoba testiranih na markere TTI prikazana je u tabeli 1 . 
Preliminarno testiranje na HBs antigen, antitela anti-HCV i anti-HIV, vršeno je na ELLISSA procesoru EIA testovima treće generacije (slika 1). Za testiranje HBsAg korišćen je test "Hepanostika HBsAg UniForm II" (slika 2). Za otkrivanje markera na antiHIV antitela upotrebljen je test "Vironostika HIV UniForm II Ag/Ab" (slika 3). Proizvođač za obe vrste testova je "The BioMérieux Clinical Diagnostics",
Francuska; Za testiranje anti-HCV antitela upotrebljen je EIA test treće generacije "Hepanostika HCV Ultra", proizvođač "Beijing United Biomedical Co.Ltd.", Kina (slika 4) [44].

Tabela 1. Struktura ispitivanih osoba testiranih na markere TTI

\begin{tabular}{|c|c|c|}
\hline \multirow{2}{*}{ Struktura ispitivanih osoba } & \multicolumn{2}{|c|}{ Osobe testirane na markere TTI } \\
\cline { 2 - 3 } & Broj testiranih (n) & Procenat testiranih (\%) \\
\hline Trudnice & 11.983 & 65,38 \\
\hline Osobe rizičnog ponašanja & 934 & 5,10 \\
\hline Osobe planirane za operaciju & 5.411 & 29,52 \\
\hline UKUPNO & 18.328 & 100 \\
\hline
\end{tabular}

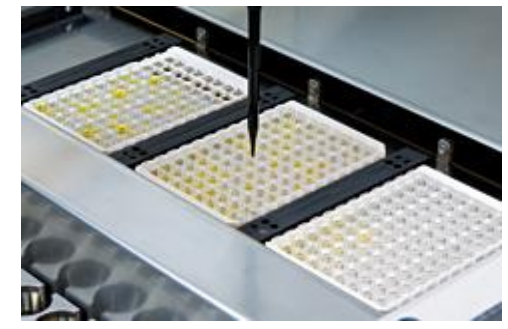

Slika 1. Mikrotitarske ploče u toku izvođenja EIA testova treće generacije [44]

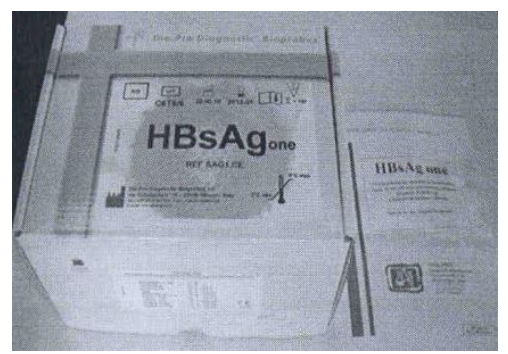

Slika 2. Test "Hepanostika HBsAg UniForm II (proizvođač BioMérieux Clinical Diagnostics", Francuska) za testiranje HBs antigena

Preliminarno pozitivni uzorci krvi ponovno su testirani istim testom (u duploj proceduri) iz novog uzorka koji je uziman u "suvoj" epruveti bez antikoagulansa, nakon 10-14 dana od utvrđene preliminarne pozitivnosti na ispitivane markere TTI. Kod ponovno pozitivnih uzoraka krvi rađen je potvrdni WB ("Western Blot") test (slika 5). Za određivanje antitela $\mathrm{u}$ humanom serumu ili plazmi, na markere TTI ("INNO-LIA

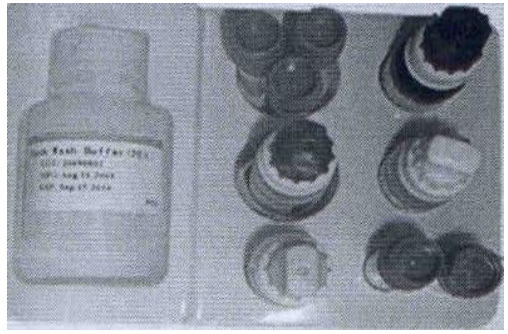

Slika 3. Test „Vironostika HIV UniForm II $\mathrm{Ag} / \mathrm{Ab}$ “ (proizvođač „BioMérieux Clinical Diagnostics" Francuska) za testiranje anti-HIV antitela

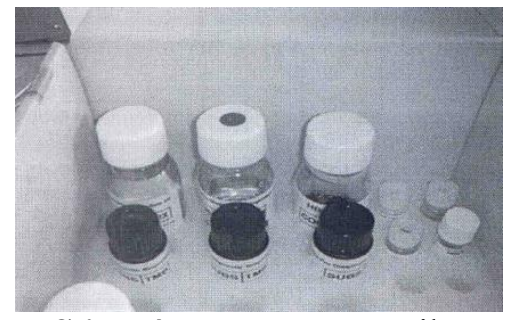

Slika 4. Test "Hepanostika HCV Ultra" (proizvođač „Beijing United Biomedical Co.Ltd.", Kina) za testiranje anti-HCV antitela

HCV Ab III"; "INNO-LIPA HBV Genotyping" i "INNO-LIA HIV I/II") proizvođač za sva tri potvrdna testa je "Innogenetics NV", Belgija. Uzorci krvi čiji su rezultati bili pozitivni na potvrdnom testu na ispitivane markere TTI, prihvaćeni su kao potvrdno $\mathrm{HBs} \mathrm{Ag}$ pozitivni, potvrdno anti-HCV reaktivni i potvrdno antiHIV reaktivni. 

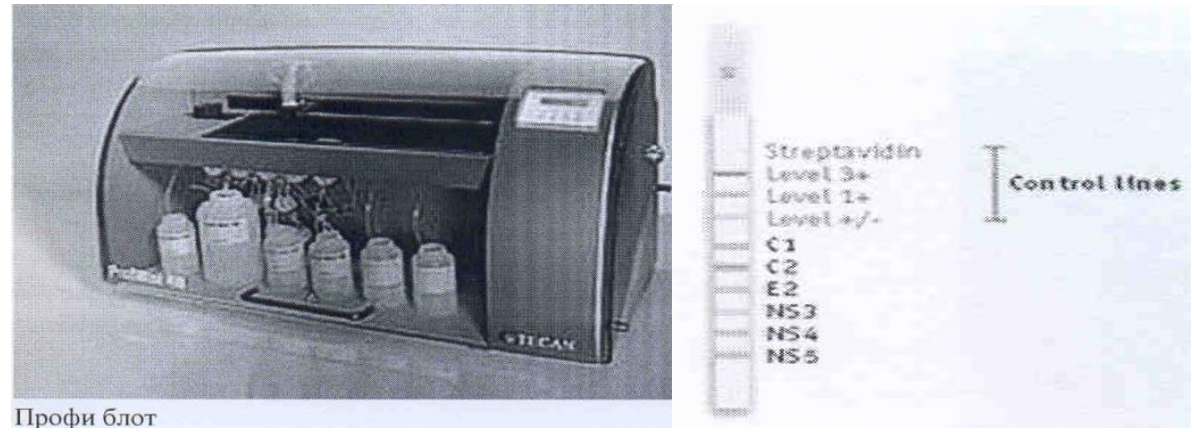

Slika 5. Potvrdni "Western blot" test: INNO-LIA HCV Ab III; INNO-LIA HIV I/II (Innogenetics NV, Belgija) i TEST NEUTRALIZACIJE HBsAg

\section{Rezultati}

Od ukupno 11.983 testiranih trudnica (tabela 2), bilo je $152(1,27 \%)$ preliminarno reaktivnih, 38 potvrdno pozitivnih $(0,32 \%)$ i $114(0,95 \%)$ lažno reaktivnih na HBsAg; 123 $(1,03 \%)$ preliminarno reaktivnih i 35 potvrdno

pozitivnih na antitelo anti-HCV $(0,29 \%), 88$ $(0,74 \%)$ lažno pozitivnih i $15(0,13 \%)$ preliminarno reaktivnih na HCV, 5 potvrdno pozitivnih $(0,04 \%)$ i $10(0,09 \%)$ lažno reaktivnih trudnica na anti-HIV antitelo.

Tabela 2. Prikaz rezultata testiranja trudnica na markere TTI

\begin{tabular}{|c|c|c|c|c|}
\hline $\begin{array}{l}\text { Rezultati testiranja na } \\
\text { markere TTI }\end{array}$ & $\begin{array}{l}\text { Preliminarno } \\
\text { reaktivni } \\
\text { n }(\%)\end{array}$ & $\begin{array}{l}\text { Lažno- } \\
\text { pozitivni } \\
\text { n }(\%)\end{array}$ & $\begin{array}{c}\text { Potvrdno } \\
\text { pozitivni } \\
\text { n }(\%)\end{array}$ & $\begin{array}{c}\text { Potvrdno } \\
\text { pozitivni na } \\
\text { Western Blot } \\
\text { n }(\%)\end{array}$ \\
\hline HBsAg negativni & $11.945(99,68)$ & & $11.831(98,73)$ & \\
\hline HBsAg pozitivni & $152(1,27)(4 X)$ & $114(0,95)$ & $38(0,32)$ & $33(0,27)$ \\
\hline $\begin{array}{c}\text { Negativni na antitelo } \\
\text { anti-HCV }\end{array}$ & $11.948(99,71)$ & & $11.860(98,97)$ & \\
\hline $\begin{array}{c}\text { Pozitivni na antitelo } \\
\text { anti-HCV }\end{array}$ & $123(1,03)(3,5 X)$ & $88(0,74)$ & $35(0,29)$ & $31(0,26)$ \\
\hline $\begin{array}{l}\text { Negativni na antitelo } \\
\text { anti-HIV }\end{array}$ & $11.978(99,96)$ & & $11.968(99,87)$ & \\
\hline $\begin{array}{c}\text { Pozitivni na antitelo } \\
\text { anti-HIV }\end{array}$ & $15(0,13)(3 X)$ & $10(0,09)$ & $5(0,04)$ & $3(0,02)$ \\
\hline Ukupno, n (\%) & $11.983(100)$ & $212(1,76)$ & $11.983(100)$ & \\
\hline
\end{tabular}

Od 934 testirane osobe sa rizičnim ponašanjem, detektovano je $36(3,85 \%)$ preliminarno reaktivnih, 28 (2,99\%) potvrdno pozitivnih i $8(0,86 \%)$ lažno reaktivnih na HBsAg; 38 $(4,07 \%)$ preliminarno reaktivnih i $33(3,53 \%)$ potvrdno pozitivnih na anti-HCV, $5(0,54 \%)$ lažno reaktivnih i $10(1,07 \%)$ preliminarno anti-HIV reaktivnih, $9(0,96 \%)$ antiHIV potvrdno pozitivnih i jedna $(0,11 \%)$ osoba sa rizičnim ponašanjem lažno reaktivna na anti-HIV (tabela 3) .

Od 5.411 testiranih, koji su planirani za operativne procedure, utvrđeno je $40(0,74 \%)$ osoba potvrdno pozitivnih na $\mathrm{HbsAg}, 38$ $(4,07 \%)$ preliminarno reaktivnih i $51(0,94 \%)$ potvrdno pozitivna trudnica na anti-HCV i 11 $(0,20 \%)$ anti-HIV potvrdno pozitivnih osoba (tabela 4). 
Tabela 3. Prikaz rezultat osoba sa rizičnim ponašanjem testiranih na TTI

\begin{tabular}{|c|c|c|c|c|}
\hline $\begin{array}{c}\text { Rezultati testiranja } \\
\text { na markere TTI }\end{array}$ & $\begin{array}{c}\text { Preliminarno } \\
\text { reaktivni } \\
\text { n (\%) }\end{array}$ & $\begin{array}{c}\text { Lažno- } \\
\text { pozitivni } \\
\text { n (\%) }\end{array}$ & $\begin{array}{c}\text { Potvrdno } \\
\text { pozitivni } \\
\text { n (\%) }\end{array}$ & $\begin{array}{c}\text { Potvrdno pozitivni } \\
\text { na Western Blot } \\
\text { n (\%) }\end{array}$ \\
\hline HBsAg negativni & $\mathbf{9 0 6}(\mathbf{9 7 , 0 1 )}$ & & $878(94)$ & \\
\hline HBsAg pozitivni & $36(3,85)$ & $8(0,86)$ & $\mathbf{2 8}(\mathbf{2 , 9 9})$ & $26(2,78)$ \\
\hline $\begin{array}{c}\text { Negativni na antitelo } \\
\text { anti-HCV }\end{array}$ & $\mathbf{9 0 1}(\mathbf{9 6 , 4 7 )}$ & & $868(92,93)$ & \\
\hline $\begin{array}{c}\text { Pozitivni na antitelo } \\
\text { anti-HCV }\end{array}$ & $38(4,07)$ & $5(0,54)$ & $\mathbf{3 3}(\mathbf{3 , 5 3})$ & $31(3,32)$ \\
\hline $\begin{array}{c}\text { Negativni na antitelo } \\
\text { anti-HIV }\end{array}$ & $\mathbf{9 2 5}(\mathbf{9 9 , 0 4 )}$ & & $925(99,03)$ & \\
\hline $\begin{array}{c}\text { Pozitivni na antitelo } \\
\text { anti-HIV }\end{array}$ & $10(1,07)$ & $1(0,11)$ & $\mathbf{9 ( 0 , 9 6 )}$ & $8(0,86)$ \\
\hline Ukupno, n (\%) & $\mathbf{9 3 4}(\mathbf{1 0 0})$ & $14(1,50)$ & $\mathbf{9 3 4}(\mathbf{1 0 0})$ & \\
\hline
\end{tabular}

Tabela 4. Prikaz testiranih bolesnika na TTI koji su planirani za operativne procedure

\begin{tabular}{|c|c|}
\hline $\begin{array}{c}\text { Rezultati testiranja na markere } \\
\text { TTI }\end{array}$ & $\mathbf{n}(\%)$ \\
\hline HBsAg negativni & $5.371(99,26)$ \\
\hline HBsAg pozitivni & $40(0,74)$ \\
\hline Negativni na antitelo anti-HCV & $5.360(99,06)$ \\
\hline Pozitivni na antitelo anti-HCV & $51(0,94)$ \\
\hline Negativni na antitelo anti-HIV & $5.400(99,80)$ \\
\hline Pozitivni na antitelo anti-HIV & $11(0,20)$ \\
\hline Ukupno, $\mathbf{n}(\%)$ & $5.411(100)$ \\
\hline
\end{tabular}

\section{Diskusija}

Osnovni razlozi za nemogućnost sprečavanja širenja markera krvlju prenosivih bolesti, tj. transfuzijski transmisivnih infekcija (TTI) su: a) nizak nivoa markera na prisustvo virusa koji su nedektabilni raspoloživim testovima; b) odsustvo markera infekcije u početnom stadijumu infekcije (period "prozora"); i c) mogućnost laboratorijske greške pri izvođenju skrining testova.

Prema utvrđenom algoritmu testiranja, uzorci krvi koji su HBs Ag pozitivni na potvrdnom testu po principu blotinga ("Western blot") RIBA testa, prihvaćeni su kao stvarno $\mathrm{HBs}$ Ag pozitivni. Dobijeni rezultati prevalence $\mathrm{HBs} \mathrm{Ag}$ pozitivnih ispitivanih osoba $\mathrm{u}$ našoj studiji na potvrdnom "Western blot"- RIBA testu (0,32 \% kod trudnica i $2,99 \%$ kod osoba sa rizičnim ponašanjem) približno su isti literaturnim podacima.

Ispitivanje prisustva $\mathrm{HBsAg}$ u serumu osoba se izvodi enzimoimunim testovima - EIA, ili još nazvanim i ELISA testovima ("Enzyme Linked Immunoapsorbent Essay"), a pored toga može se dokazati u citoplazmi hepatocita pomo- ću imunoelektronskog mikroskopiranja (IEM) [2-6, 8-16]. Na osovu dosadašnjih saznanja [1-6, 11] poznato je da se u centru viriona nalazi tzv. "core antigen" (označen simbolom HBcAg) koji sadrži DNK i odgovarajuću DNK polimerazu. Almeida sa saradnicima, prvi je dokazao $\mathrm{HBcAg}$ prilikom lize viriona deterdžentima $[9,11,14]$. HBcAg se može detektovati u jedru a ponekad i u citoplazmi hepatocita pomoću IEM [2-6, 8-11]. Treći antigen HBV nazvan je HBeAg-om, solubilan je i za njega se smatra da je produkt katalize (cepanja) HBcAg-a. Njegovo prisustvo u serumu ukazuje na fazu aktivne replikacije virusa, odnosno visoke infektivnosti osobe [2-6]. Svaki od napred navedenih antigena može dovesti do stvaranja specifičnih antitela, označenih simbolima anti-HBs, anti-HBc i anti-HBe. Pored opisanog "klasičnog" HBV, poznata je i posebna varijanta virusa, nazvana HBV-2 i njega karakteriše da ne indukuje sintezu antitela anti-HBc i anti-HBe. Varijanta HBV-2 javlja se kao rezultat strukturnih promena $\mathrm{HBV}$-a, najverovatnije da se 
radi o promena u sekvenci $\mathrm{HBcAg-a}[8-11,20-$ 22].

Laboratorijska dijagnoza infekcije HBVom podrazumeva izvođenje specifičnih seroloških testova kojima se dokazuje prisustvo različitih markera infekcije. Na osnovu dosadašnjih saznanja akutna infekcija se karakteriše pojavom HBsAg, HBeAg i specifične DNK HBV-a, odnosno polimeraze DNK. Nakon toga se u cirkulaciji inficiranih osoba pojavljuje antitelo anti-HBc (najpre klase IgM, a zatim IgG) [20-22]. Sadašnjim serološkim testovima može se otkriti HBsAg u koncetraciji od $0,2-0,5 \mathrm{ng} / \mathrm{mL}$ ili oko $3 \times 10^{7} \mathrm{HBs} A g$ partikula u $\mathrm{mL}$ plazme $[2-6,20-$ 22].

Kao što je već rečeno, danas se najčešće za preliminarna testiranja koriste EIA testovi, poznati još i kao ELISA testovi. Za potvrdna testiranja u upotrebi su testovi po principu blotinga ("Western blot"). Mada su današnji skrining i potvrdni testovi znatno smanjili rizik od prenošenja transfuzijski transmisivnih bolesti, najnoviji visoko osetljivi metod, najsavremenijom tehnologijom "Nucleic Acid" (PCR) testiranja, daje mogućnost svođenja transmisije uzročnika transmisivnih bolesti na još manju meru. Pomoću NAT tehnike moguće je direktno detektovati infektivni agens u krvi u vrlo maloj koncentraciji čak i pre nego što se stvore antitela. Primenom nove tehnike period "prozora" pri detekciji HCV-a skraćen je sa 82 dana na 57 dana, a kada je u pitanju testiranje na prisustvo HIV-a, taj period je sveden sa 22 dana na samo 12 dana [2-6].

$\mathrm{Na}$ osnovu rezultata preliminarnog i potvrdnog testa, sve testirane osobe se svrstavaju u sledeće 4 kategorije [1-6]: stvarno pozitivne; lažno pozitivne; lažno negativne i stvarno negativne.

$\mathrm{Na}$ osnovu međusobnog odnosa ovih grupa definišu se osetljivost i specifičnost, dva osnovna parametra koji karakterišu pouzdanost testa. Osetljivost preliminarnog testa definisana je učestalošću pozitivnih EIA rezultata dobijenih testiranjem populacije stvarno pozitivnih individual $[0=A /(A+C) \%]$. Specifičnost je svojstvo testa da neinficirane osobe označi kao negativne $[S=D(D+B) \%]$, a vrednosti osetljivosti i specifičnosti deklarisane od strane proizvođača testova kreću se od $98,3 \%$ do $100 \%$ i od $99,2 \%$ do $100 \%$ [1-3].

Epidemiološka ispitivanja u našoj zemlji su pokazala da je HBs Ag prisutan u 0,3 - 0,5\% dobrovoljnih davalaca krvi. Rizik od posttransfuzijskog hepatitisa tipa B iznosi oko 1/66.000 jedinica krvi [1-6, 11-14]. Jedna studija testiranja na HBs Ag, sprovedena u našoj zemlji na malom broju ispitanih zdravstvenih radnika u pripremi za vakcinaciju protiv hepatitisa tipa B, pokazala je prevalencu od $0,46 \%$ stvarno HBs Ag pozitivnih (što se uklapa u evropski standard koji važi za zdrave populacije) [22].

Dobijeni rezultati prevalence pozitivnih rezultata na antitela anti-HCV ispitivanih osoba u našoj studiji su na potvrdnom RIBA testu $(0,29 \%$ kod trudnica i 3,53\% kod osoba sa rizičnim ponašanjem) približno isti sa literaturnim podacima.

Naše ispitivanje je potvrdilo da je u grupi osoba sa rizičnim ponašanjem najveća prevalenca obolelih od virusa hepatitisa tipa $\mathrm{C}$, koja prevazilazi ukupnu prevalencu oboljevanja od HCV infekcije od 3\%, a da je znatno veća od prevalence oboljevanja u našoj zemlji koja se kod dobrovoljnih davalaca kreće 0,2 do $2 \%[4,5,23]$.

Epidemiološko ispitivanje sprovedeno 1989. godine u 19 zemalja Evrope dalo je prevalencu anti-HCV antitela kod $0,57 \%$ dobrovoljnih davalaca krvi [2-6, 23]. Ranija ispitivanja pokazala su prevalencu antitela antiHCV kod $0,71 \%$ dobrovoljnih davalaca krvi $[4,5]$. Dobijeni rezultati prevalence potvrdno anti-HCV antitela, pozitivni u studiji sprovedenoj u VMA (2004./5) kod 37.401 dobrovoljnih davalaca krvi $(0,28 \%)$ slični su literaturnim podacima [3, 4].

Prevalenca pozitivnih dobrovoljnih davalaca krvi $(0,15 \%)$ na antitela anti-HCV sa NAT (PCR) - HCV tehnologijom dobijena u studiji u VMA ukazuje na to da je NAT (PCR) - HCV testiranje daleko preciznije i pouzdanije [2-6]. NAT (PCR) - HCV testiranje pruža veću sigurnost $\mathrm{u}$ hemoterapiji, i ako se radi se o "skupoj" tehnologiji. "Cost benefite" (pozitivan efekat cene koštanja testa) je ipak veći zbog sigurnosti terapije krvlju i/ili krvnim produkti- 
ma (hemoterapije) $[2-6,16,23]$. Oko 3\% stanovništva u svetu zaraženo je HCV-om. Prevalenca HCV-a u Evropi, SAD, Kanadi i Australiji niža je od $1,5 \%$, u Africi i jugoistočnoj Aziji prevalenca oboljevanja je viša od 2,5\%, a na Bliskom istoku iznosi preko 12\%. Infekcija HCV-om je uz infekciju HBVom jedan od najznačajnijih javnozdravstvenih problema u svetu. Sedamdesetih godina prošlog veka nije još bila otkrivena struktura HCV-a pa je on nazvan "non-A, non-B" virus hepatitisa. Tek 1989. godine opisan je ovaj virus i nazvan hepatitis $\mathrm{C}$ virus (HCV). Virus je klasifikovan prema analizi nukleotidne sekvence, ali još uvek nije nije uspela izolacija virusa i njegova kultivacija. Uzrokuje perzistentnu infekciju koja u 60 do $80 \%$ inficiranih prelazi u hronični hepatitis, $25 \%$ oboli od ciroze jetre a 7 do $10 \%$ pacijenata obolelih od perzistentne infekcije $\mathrm{HCV}$-om u terminalnom stadijumu oboli od hepatocelularnog karcinoma. Infekcija HCV-om prenosi se parenteralnim putem (posebno putem transfuzije krvi i/ili hemoprodukata, dijalizom, upotrebom inficiranih špriceva kod narkomana) i seksualnim putem. Nakon infekcije sledi period inkubacije koji traje od 2 nedelje do 6 meseci, prosečno 78 nedelje. Akutna infekcija HCV-om može se ispoljiti kao klinički manifestni hepatitis, međutim $2 / 3$ akutnih infekcije prolazi asimptomatski. Bolesnikov imuni sistem teško eliminiše uzročnike tako da akutna infekcija u 60 do $80 \%$ bolesnika prelazi u hronični oblik. U 20 do $30 \%$ bolesnika nastaje spontana eliminacija infekcije i HCV-a. U ostalih bolesnika virus perzistira u hepatocitima, što se dokazuje prisustvom virusne RNA u krvi. U nekih bolesnika koncentracija antitela anti-HCV-a varira, tj. periodično se povećava i snižava ispod granice osetljivosti testa. Zbog toga i anti-HCV antitela negativne osobe koje su prebolele hepatitis $\mathrm{C}$ mogu biti infektivne. Kod njih je potrebno NAT (PCR) - HCV testom dokazati da više nisu infektivne [2-6, 11-14]. Prevencija posttransfuzijskog hepatitisa C sprovodi se, uz ostale mere i obaveznim testiranjem dobrovoljnih davalaca krvi na antitela anti-HCV, kao i NAT (PCR)-HCV testiranjem dobrovoljnih davalaca čija će se plazma upotrebiti u proizvodnji krvnih derivata.
Dijagnostički "prozor" u zarazi HCV-om izuzetno je dug i znatno se skraćuje testiranjem NAT (PCR)-HCV ili testiranjem antigena HCV-a. Ovim testiranjem se sa 66 do 72 dana period "prozora" skraćuje na 7 do 9 dana [2, 3]. Srednji inkubacioni period iznosi 5 do 12 nedelja, mada se sa većim inokulumom u hemoproduktu, kao što je primenjivanje VIII činioca koagulacije, period inkubacije može skratiti na 4 nedelje ili manje [24-30]. Tipičan klinički tok se ne razlikuje od drugih formi virusnog hepatitisa i ne može biti izdvojen kliničkim nalazima ili rutinskim biohemijskim testovima [3, 4, 24-28].

Akutna infekcija HCV-om je najčešće klinički srednje izražena manifestacija bolesti. Maksimalna aktivnost enzima jetre ALT (adenin-laktat-transferaza) je niža nego kod obolelih od akutnog hepatitisa tipa A ili hepatitisa tipa B. Vrednost može da se menja, fluktuira, a može da bude i u fiziološkim granicama. Samo $25 \%$ osoba ispolji ikterus, trajanja od nekoliko dana do nekoliko meseci, mada u proseku iznosi manje od mesec dana. Kao posledica preležanog hepatitisa nastaju sekvele kao što su ciroza jetre ili hepatocelularni karcinom. Pruritus i steatoreja su propratne pojave kao i prosečni gubitak u telesnoj težini od 2 do $5 \mathrm{~kg}$. Slabost može biti ispoljena u dužem periodu [24-28]. Većina bolesnika sa hroničnim hepatitisom tipa $\mathrm{C}$ je bez, ili sa srednje izraženim simptomima. Kod bolesnika sa ispoljenim simptomima, slabost je česta pojava i manifestuje se nedostatkom energije i povećanom potrebom za snom. Bolest ima spor progresivan tok sa manjim porastom mortaliteta posle 20 godina od oboljevanja. Ciroza jetre se evidentira kod $20 \%$ bolesnika sa hroničnom bolešću a fulminantni oblik hepatitisa tipa $\mathrm{C}$ je izuzetno redak. Među primaocima transfuzija, ova pojava je sporadična te su i publikovani izveštaji samo o pojedinačnim slučajevima [3, 4, 24-28].

Do sada objavljeni radovi su pokazali prisutnost antitela anti-HCV kod različitih populacionih grupa. Velike grupe čine davaoci krvi, kod kojih prevalenca iznosi od 0,2 do $2 \%$. Sa godinama života učestalost raste, ali bez evidentne razlike u polovima, kao i geografskoj lokaciji. U našoj zemlji prevalenca antite- 
la anti-HCV u populaciji dobrovoljnih davalaca krvi iznosi 0,3\% [24].

Osobe inficirane HCV-om se dele na: 1) primaoce $\mathrm{krvi} \mathrm{i} / \mathrm{ili}$ hemoprodukata, 2) primaoce organa i tkivnih transplantata, 3) uživaoce intravenskih droga, 4) inficirane osobe nedefinisanim putem (sporadično ili stečeno sa nedefinisanim rizičnim faktorom), 5) osobe $u$ bliskom kontaktu sa obolelim [3,4, 24-30]. Iako je mehanizam prenošenja HCV-a sličan HBV-u, uočene su i neke značajne razlike $[4,5,23]$. Kod $43 \%$ HCV bolesnika put prenošenja je nedefinisan, češće oboljevaju osobe iz grupe uživalaca intravenskih droga ili oni koji su bili direktno eksponirani HCV-om. U ovoj grupi su i bolesnici sa anamnestičkim podacima da su primili transfuziju krvi i/ili hemoprodukte, kao i zravstveni radnici koji su bili u kontaktu sa obolelima od hepatitisa tipa C [23].

Kao prva linija prevencije, preporučuje se vakcina za zaštitu od infekcije HCV-a. Vakcina za zaštitu protiv infekcije HCV-om za sada još uvek nije moguća i zahteva izvesno vreme da bi se proizvela. Pasivna zaštita, odnosno primena specifičnih imunoglobulina sa visokim titrom je takođe $\mathrm{u}$ ovom trenutku nemoguća. Zbog toga, sprečavanje prenošenja infekcije može se postići samo sprečavanjem izloženosti HCV-u. To može biti indirektno, skriningom jedinica krvi i davalaca organa na antitela anti-HCV primenom najsavremenije NAT (PCR) - HCV. Skrining davalaca krvi i organa će u većini slučajeva sigurno sprečiti prenošenje antitela anti-HCV primaocima krvi ili organa zbog čega oni neće ni biti eksponirani HCV-om [3, 4, 24-30].

Dobijeni rezultati prevalence potvrdno anti-HIV-antitelo pozitivnih ispitivanih osoba u našoj studiji na RIBA testu $(0,04 \%$ kod trudnica i $0,20 \%$ kod osoba sa rizičnim ponašanjem) približno su isti sa podacima iz dostupne literature. Naše ispitivanje je potvrdilo najveću prevalencu obolelih od HIV-a u grupi osoba sa rizičnim ponašanjem $(0,94 \%$ osoba je pozitivno na antitela anti-HIV).

HIV je otkriven 1979. godine; HIV-1 tip virusa je izolovan iz ćelija inficiranog bolesnika 1983. godine a 1986. godine izolovan je i HIV-2 tip kao uzročnik iste bolesti. HIV-1 i
HIV-2 su morfološki slični, s tim da je poslednji manje patogen. HIV pripada grupi humanih retrovirusa a porodici lentivirusa. Prva epidemija AIDS-a je izbila 1979. godine u SAD (New York, San Francisko, Los Angeles). Do sada prisutna saopštenja pokazuju da je ova bolest prisutna u celom svetu i da postoji stalni eksponencijalni rast obolelih od AIDS-a. Prva saopštenja su govorila da je bolest prisutna posebno u grupi homoseksualaca, bolesnika obolelih od hemofilije i starosedelaca Haitija (3H) [2,3].

Do juna 1995. godine SZO je bilo prijavljeno 1,17 miliona slučajeva AIDS-a, a smatra se da je stvaran broj oko 4,5 miliona ljudi. Procenjuje se da je oko 18,5 miliona ljudi inficirano HIV-om. SZO procenjuje da je više od $70 \%$ inficiranih u Africi, $18 \%$ u Americi, a nešto manje od $6 \%$ u Aziji. Seroprevalenca među davaocima krvi je vrlo šarolika počev od 0 do ozuzetno visoke od $16 \%$ do $21 \%$. U industrijski razvijenim Zemljama gde se vrši sistematsko ili selektivno skriningovanje davalaca krvi na prisustvu anti-HIV1 i anti-HIV2, a $\mathrm{u}$ poslednje vreme $\mathrm{i}$ na anti-HIV1 podtip 0 , rizik od transmisije virusa je skoro eliminisan [19].

Centar za kontrolu/klasifikaciju bolesti u SAD je dao parametre za dijagnostikovanje AIDS-a [2, 3, 19], a to su:

1. broj $\mathrm{CD}^{+} \mathrm{T}$-limfocita manji od $200 / \mathrm{mm}^{3}$;

2. prisustvo oportunističkih infekcija tipa kandidijaze bronha, traheje ili pluća; kandidijaze jednjaka; ekstrapulmonalne hronične kokcidioza; hronične intestinalne kriptosporidioza; citomegalovirusne infekcije; citomegalovirusnog retinitisa; herpes simplexa; diseminovane ili ekstrapulmonalne histoplazmoze; hronične, intestinalne izosporioze; diseminovane ili ekstrapulmonalne mikobakterijalne infekcije; mikobakterija tuberkuloze; pneumocistis carini pneumonia; pneumonia recurrens; salmonella septicemia, recurrent toxoplasma CNS.

3. prisustvo malignih oboljenja: karcinom grlića materice; Kapošijev sarkom; Burkitt-ov limfom; imunoblastični limfom; 
primarni limfom mozga;

4. encefalopatija (AIDS demencija);

5. progresivna multifokalna leukoencefalopatija

Detektabilni znaci infekcije koji se javljaju u krvi za vreme ili posle infekcije nazivaju se markerima infekcije. Rezultati testiranja na antitela anti-HIV klasifikuju se kao: negativan/pozitivan (određen statusom davaoca); nereaktivan/reaktivan i neodređen [2,3].

Prva generacija EIA testova koja je zasnovana na virusnim antigenima dobijenim razlaganjem (lizat) humane ćelijske kulture u kojoj je kultivisan HIV, ima određene prednosti u odnosu na nove generacije testova (drugu i treću). Ova prednost se, pre svega, ogleda u činjenici da antigeni HIV-a prisutni u lizatu po fizikohemijskim i strukturnim karakteristikama u potpunosti odgovaraju antigenima u serumima inficiranih osoba. To znači da je za vezivanje antitela dostupan najveći broj epitopa na različitim proteinima HIV-a na koje normalno reaguje imuni sistem inficiranih individua. Ovi uslovi značajno doprinose poboljšanju osetljivosti testa (smanjenju broja lažno negativnih rezultata) povećavajući verovatnoću da se u serumu inficirane osobe nađe anti-HIV koje će se vezati za korespondentni epitop u lizatu [3338]. Osnovni nedostatak testova zasnovanih na virusnom lizatu predstavlja prisustvo ćelijskih antigena najčešće MHC II molekula ali i drugih receptora na koje postoje indukovana antitela u serumima neinficiranih osoba, kao što je slučaj kod različitih autoimunih obolenja, nekih malignih obolenja ili drugih uslova vezanih za disfunkciju imunog sistema, a to stvara uslove za pojavu lažno reaktivnih rezultata testa.

Druga generacija EIA testova koristi rekombinantne proteine dobijene tehnikom rekombinovane DNK tako da su antigeni dobro definisani, što doprinosi povećanju specifičnosti testa, odnosno smanjenju broja lažno reaktivnih rezultata.

Treća generacija EIA testova koristi sintetske peptide dobijene tehnologijom peptidne sinteze, gde su takođe jasno definisani antigeni koji veoma specifično vežu antitela iz seruma inficiranih osoba.
Pogodnim izborom antigena (najčešće je to glikoprotein virusnog omotača gp $160 \mathrm{u}$ slučaju rekombinantnog proteina ili peptidi iz transmembranskog proteina gp41 i cor proteina p24), povećana je mogućnost rane detekcije serokonverzije [33-39] i u odnosu na test prve generacije iznosi 30 dana. Prednost se ogleda i u mogućnosti reproducibilnosti rezultata, koja ne zavisi od proizvođača već isključivo od vrste korišćenog rekombinantnog proteina ili peptida, što nije slučaj sa anti-HIV EIA testovima zasnovanim na virusnim lizatima. Nedostatak ovih testova je ograničen broj epitopa, te je povećana verovatnoća da, i pored njihovog pažljivog izbora u testiranom serumu inficirane osobe ne bude odgovarajućih antitela ili, pak, da nihov titar bude ispod granice osetljivosti testa. Ovi uslovi značajno utiču na smanjenje osetljivosti testova druge i treće generacije povećavajući verovatnoću pojave lažno negativnih rezultata [33-39].

Razlozi za nemogućnost ranog otkrivanja HIV-a su: nizak nivoa markera na prisustvo HIV-a koji su nedektabilni raspoloživim testovima; odsustvo markera infekcije u početnom stadijumu infekcije (period "prozora") i mogućnost laboratorijske greške pri izvođenju skrining testova na markere HIV-infekcije. Primenom testova prve generacije odobrene od strane Agencije za hranu i lekove SAD (FDA), 1985. godine mogla su se detektovati antitela protiv HIV-a od 51. do 55. dana od inficiranja, a uvođenjem testova druge i treće generacije (1992. godina) taj period je skraćen na 22 dana [2-6, 19].

U savremenim transfuziološkim laboratorijama se primenjuje $\mathrm{i}$ test na prisustvo antigena p24 čime se skraćuje period serokonverzije tj. "period prozora" je skraćen na 12 dana. Preporuke Američke asocijacije banaka krvi $[8,9]$ pri testiranju dobrovoljnih davalaca su prikazane u figuri 1.

Prema podacima nacionalne referentne laboratorije Crvenog krsta SAD, rizik od posttransfuzijske infekcije HIV-om u SAD je 1 : 450.000 do $1: 600.000$ po jedinici krvi (uvođenjem testova na prisustvo p24 antigena) [9]. Prevalenca anti-HIV u bivšoj Jugoslaviji u populaciji dobrovoljnih davalaca krvi iznosi $0,001 \%$ [23]. 


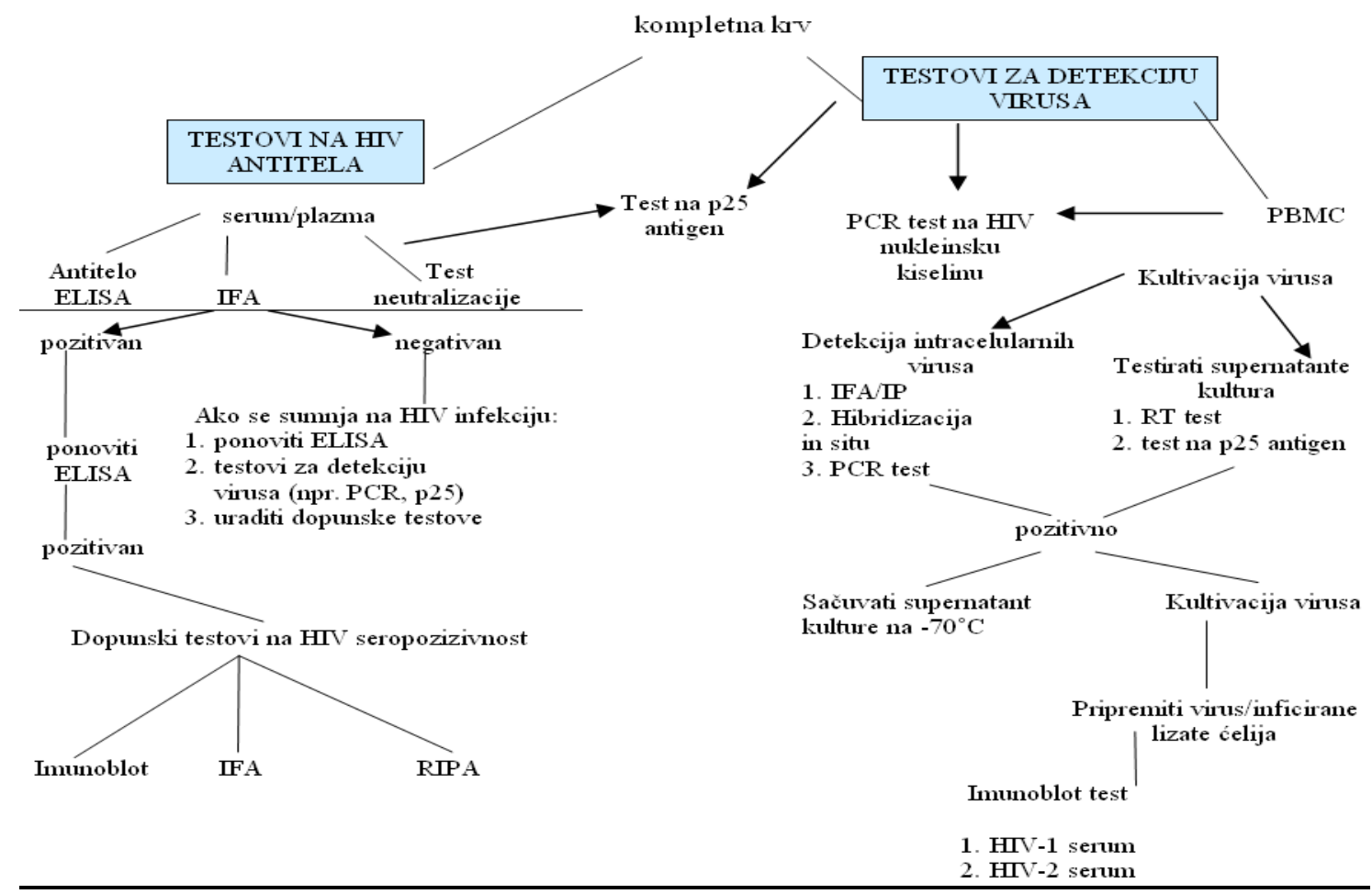

Figura 1. Algoritam testiranja uzoraka krvi dobrovoljnih davalaca krvi sa pozitivnim rezultatom na antitela anti-HIV-1/HIV-2 (izvor: Stanković B, i sar. Prevalenca virusa hepatitisa B (HBV), hepatitis C virusa (HCV) i virusa humane imunodeficijencije (HIV) kod trudnica i kod osoba sa rizičnim ponašanjem. U: Zagorac D. (ur). Svet rada časopis za pitanja bezbednosti i zaštite zdravlja na radu, medicine rada i zaštite životne sredine. 2004, p.431.)

Putevi prenošenja HIV infekcije su dobro poznati, i definisani kao [2, 3]:

1) penetrirajući seksualni kontakt sa inficiranom osobom bilo da je to muškarac ili žena;

2) primena kontaminiranih igala, špriceva (i.v. uživaoci droga i višekratna upotreba instrumenata ili skalpela) kao i ritualna skarifikacija kože ili tetovaža;

3) transfuzija krvi i/ili produkata od krvi i

4) sa inficirane majke na dete (in utero, tokom porođaja i mlekom);

Svakako, najčešći i najznačajniji način prenošenja infekcije HIV-a je seksualnim putem. Efekat heteroseksualne transmisije je naročito izražen u Africi gde porast broja inficiranih žena (horizontalni put) dovodi i do porasta broja inficirane dece (vertikalni put). $\mathrm{Na}$ taj način HIV se širi izuzetno brzo.

Procenjuje se da bi više od $90 \%$ primalaca transfuzija obolelo ukoliko bi se transfundovala HIV pozitivna jedinica krvi. SZO je objavila podatak da transfuzija jedne jedinice HIV pozitivne krvi dovodi, kod dece, do smrti već posle dve godine od primljene transfuzije, a kod odraslih u roku od 3-5 godina [2-6].

Kod većine inficiranih, u serumu se mogu dokazati antitela protiv HIV virusa. Krv davaoca koja je anti-HIV reaktivna ne sme se upotrebljavati za transfuziju. HIV ulazi u T limfocite i zbog toga se ne može otkriti njegova prisutnost u krvi inficirane osobe. Osobe inficirane HIV-om, stvaraju anti-HIV antitela i njihova prisutnost znači kontakt ili infekciju sa HIV-om. Antitela protiv HIV-a nađena su u gotovo $100 \%$ bolesnika sa AIDS-om.

Zbog brzog širenja infekcije i težine bolesti, AIDS je postao jedan od osnovnih socijalnih i zdravstvenih problema zdravstvene službe i transfuziologije. Testiranje dobrovoljnih davalaca krvi na HIV, obavezno je našim zakonom od 1987. godine. U svim zdravstvenim ustanovama neophodno je sprovoditi mere kojima će biti zaštićeni zdravstveni radnici i primaoci transfuzije krvi [2-6]. Tokom ranog perioda infekcije, viremija se otkriva detektovanjem HIV RNK u plazmi obolelog pomoću tehnike 
lančane reakcije polimeraze (PCR) 12. dana od inficiranja, a prisustvo anti-HIV specifičnih antitela kao specifičan marker infekcije 22. dana od inficiranja $[2,3]$. U populaciji gde je niska učestalost infekcije HIV-om, kao i tamo gde je dobro organizovan skrining program testiranja, transmisija virusa transfuzijom je vrlo retka, a u populaciji gde je visoka učestalost virusa i program za testiranje na niskom nivou, učestalija je i transmisija virusa.

glasiti da:

Sa epidemiološkog stanovišta treba na-

1. ne postoje dokazi da se neseksualnim kontaktom prenosi infekcija, jer virus nije stabilan i može lako da se uništi u spoljnoj sredini;

2. ne postoje dokazi da se infekcija širi pomoću vektora (insekata) u Africi ili bilo kom drugom području sveta. Značajno je istaći da ne postoje dokazi da se HIV razmnožava u bilo kojoj vrsti zglavkara;

3. zdravstveni radnici mogu biti u povećanom riziku samo ukoliko se ne pridržavaju osnovnih i specijalnih mera zaštite i prevencije,

Poznavanje epidemiologije i puteva prenošenja HIV-a određuje mere prevencije. Iako se ulažu veliki napori u iznalaženju vakcine protiv AIDS-a, do danas je, zbog kompleksnosti virusa, sve ostalo na eksperimentom nivou [3343].

Tok bolesti nakon infekcije HIV-om značajno je teži nego sa drugim izazivačima krvlju prenosivih bolesti. Spontana eliminacija HIV-a za sada nije poznata, dok eliminacija HBV-a nastaje u velikoj većini bolesnika, a HCV-a u manjem broju zaraženih. HTLV-1 uzrokuje bolest (leukemiju limfocita $\mathrm{T}$ odraslih osoba, ili tropsku spastičnu paraparezu) nakon decenije inkubacije, i to u manje od $10 \%$ inficiranih. Celi niz virusnih, krvlju prenosivih bolesti prolazi asimptomatski, bez prepoznatljivih početnih simptoma nakon HIV infekcije. Markeri infekcije uzročnicima krvlju prenosivih bolesti mogu se dokazati modernim laboratorijskim metodama već nakon nekoliko dana ili nedelja od zaraze ("fenomen prozora" upotrebom PCRa skraćen je na 12 dana), i potrebno je da prođe desetak godina od zaraze do manifestacije bolesti AIDS-a. Preventivne mere u cilju sprečavanja širenja HIV infekcije moraju biti sve- obuhvatne. To podrazumeva obuhvatanje svih puteva prenošenja u modernom društvu (detaljni odabir i "skrining" davaoca da se "izbegnu" narkomani, homoseksualci, heteroseksualci i sve osobe sa rizičnim ponašanjem, itd.). Posebnu pažnju treba usmeriti na edukaciji celokupne populacije sa akcentom na zaštitu medicinskog osoblja koje je u direktnom kontaktu sa obolelima od HIV-a i infektivnim materijalom [16].

Preventivne mere za suzbijanje TTI sastojale bi se u široj edukaciji stanovništva o putevima širenja krvlju prenosivih bolesti i njihovoj prevenciji: testiranju krvi i krvnih produkata testovima najnovije generacije i pravilnom izvođenju medicinskih intervencija uz poštovanje principa asepse $i$ antisepse [16, 44-6].

\section{Zaključak}

Možemo zaključiti da su u našoj studiji ostvareni svi postavljeni ciljevi, sa posebnim akcentom na utvrđivanju algoritma testiranja na markere TTI, čime je određena prevalencija krvlju prenosivih bolesti u različitim kategorijama ispitanika i dato poređenje naših rezultata sa podacima iz dostupne literature.

Naši rezultati sugerišu da je veća prevalenca HAV, HCV i HIV-a kod osoba sa rizičnim ponašanjem $u$ odnosu na trudnice. Dobijeni rezultati pokazuju veću razliku u nalazu lažno reaktivnih rezultata kod trudnica, $u$ odnosu na lažno reaktivne rezultate kod osoba rizičnog ponašanja. Studija takođe ukazuje i na sledeće bitne naučno izvedene činjenice (koje se sreću i u dostupnoj medicinskoj literaturi), a to su: prevalenca ispitivanih markera na TTI najveća je u grupi osoba sa rizičnim ponašanje, širok dijapazon faktora rizika i ozbiljnost TTI (visok morbiditet i mortalitet kod nas i u svetu), kao i otežana serološka dijagnostika i mogućnost laboratorijske greške (nizak nivo ili odsustvo markera TTI zbog dugog perioda "prozora").

Sukob interesa: autori izjavljuju da nemaju sukob interesa. 


\section{Literatura}

1. Stanković B, Trkuljić M, Balint B. Ispitivanje prevalence $\mathrm{HBs}$ antigen pozitivnih $\mathrm{i}$ anti-HCV reaktivnih dobrovoljnih davalaca krvi. Anestezija Reanimacija Transfuzija. 2006; 34 (1/2): 193-202.

2. Vasiljević N, Trkuljić M. Hematogene transmisivne bolesti. In: Balint B, Trkuljić M. et al, editors. Osnovi transfuziologije. Beograd: Čigoja štampa; 2002. p. 435-70.

3. Haass KA, Sapiano MRP, Savinkina A, Kuehnert MJ, Basavaraju SV. TransfusionTransmitted Infections Reported to the National Healthcare Safety Network Hemovigilance Module. Transfus Med Rev. 2019; 33(2): 84-91. doi: 10.1016/ j.tmrv.2019.01.001. PMID: 30930009.

4. Taseski J, Balint B, Vasiljevic N, Andrić Z, Stanković B, Vučetić B, et al. Transfuzijski transmisivne bolesti. Bilt Transfuziol. 2004; 50 (1-2): 69-81.

5. Niederhauser C [Transfusion-transmitted Infections: How Useful and Costly is Testing for new Infectious Disease Pathogens?]. Praxis (Bern 1994). 2018; 107 (9-10): 521-9. [Article in German]. doi: 10.1024/1661-8157/a002967. PMID: 29690842.

6. Hoad VC, Styles CE, Seed CR, Kiely P, Gosbell IB. Confirming transfusion-transmitted viral infections in the molecular age: time to get back to the basic definition of infection for hemovigilance. Transfusion. 2019. [Epub ahead of print] doi: 10.1111/trf.15598. PMID:31758813

7. Goodnough LT, Hollenhorst MA. Clinical decision support and improved blood use in patient blood management. Hematology Am Soc Hematol Educ Program. 2019; 2019(1): 577-82. doi: 10.1182/hematology. 2019000062.PMID:31808902.

8. Walker RH, Branch DR, Dzik WH. editors. Technical manual. $11^{\text {th }}$ ed. Bethesda: Ameri can Association of Blood Banks, 1993.

9. Ait Bouchrim SA, Haddad A, Bou Assi T, Oriol P, Guyotat D, Bois C, Garraud O. Residents' knowledge in transfusi- on medicine and educational programs: A pilot study. Transfus Clin Biol. 2019. pii: S1246-7820(19)30450-1. doi: 10.1016/ j.tracli.2019.10.002. PMID:31735608.

10.Maitta R. Editor. Clinical practice of Transfusion Medicine, 1st. Amsterdam: Elsevier, 2018

11.Seeff BL Dienstag LJ. Transfusiontransmitted hepatitis A, B and D. In: Rossi CE, Simon LT, Moss SG, editors. Principles of transfusion medicine. Baltimore: Williams and Wilkins, 1991. p. 561-81.

12.Rasche A, Sander AL, Max Corman V, Drexler JF. Evolutionary biology of human hepatitis viruses. J. Hepatol. 2019, 70, 50120. doi: 10.1016/j.jhep.2018.11.010. PMID:30472320.

13.Haass KA, Sapiano MRP, Savinkina A, Kuehnert MJ, Basavaraju SV. TransfusionTransmitted Infections Reported to the National Healthcare Safety Network Hemovigilance Module. Transfus Med Rev. 2019; 33(2):84-91. doi: 10.1016/j.tmrv. 2019.01.001. PMID:30930009.

14.Laurain A, Pol S. [Not Available]. Bull Acad Natl Med. 2016; 200(1): 47-58. PMID: 29889412.

15.Bisceglie MA. New hepatits viruses: adding to the alphabet soup. Viral Hepatitis. 1995;1:3-5.

16.Dobec M. Zarazne bolesti uzrokovane transfuzijskim liječenjem. In: Grgičević D, et al., editors. Transfuzijska medicina $\mathrm{u}$ kliničkoj praksi. Zagreb: Medicinska naklada; 2006. p. 483-502.

17.Dogbe EE, Arthur F. Diagnostic accuracy of blood centers in the screening of blood donors for viral markers. Pan Afr Med J. 2015; 20:119. doi: 10.11604/pamj. 2015.20.119.5263. PMID:26090067.

18.Pau PC, Hu JD, Spruill C, Schable C. Surveillance for human immunodeficiency virus type 1 group 0 infections in the United States. Transfusions. 1996; 36:398-400. DOI:10.1046/j.1537-2995.1996. 36596282582.x. PMID:8693502. 
19.Dean CL, Wade J, Roback JD. TransfusionTransmitted Infections: an Update on Product Screening, Diagnostic Techniques, and the Path Ahead. J Clin Microbiol. 2018; 56(7). doi: 10.1128/JCM.00352-18. PMID:29669792.

20.Lizuka H. Ohmura K. Corellation between anti-HBc titers and HBV DNA in blood units without detectabile HBsAg. Vox Sang. 1992;63:107-11. DOI:10.1111/j.1423-0410. 1992.tb02495.x. PMID: 1441302.

21.Seiz PL, Mohr C, Wilkinson DE, Ziebuhr J, Schüttler CG, Gerlich WH, Glebe D. Characterization of the 3rd International Standard for hepatitis B virus surface antigen (HBsAg). J Clin Virol. 2016; 82: 166-72. doi: 10.1016/j.jcv.2016.05.009. PMID: 27345250.

22.Ranković N, Libek V, Gruden S, Popov D. Rezultati testiranja na markere infekcije virusom hepatitisa tipa B u cilju primene odgovarajuće vakcine. Bilt transf. 1993; 21 (3): $37-8$.

23.Vučetić D, Jovičić M, Maslovarić I, Bogdanović S, Antić A, Stanojković $\mathrm{Z}$, et al. Transfusion-transmissible infections among Serbian blood donors: declining trends over the period 2005-2017. Blood Transfus. 2019; 17(5): 336-46. doi: 10.2450/ 2019.0185-18. PMID: 30865580.

24.Bonnemain CL, Cochand L, Portmann A, Béguelin C. Recent advances in managing hepatitis D]. Rev Med Suisse. 2019; 15(666):1802-6. [Article in French] PMID: 31599521.

25.Lanini S, Ustianowski A, Pisapia R, Zumla A, Ippolito G. Viral Hepatitis: Etiology, Epidemiology, Transmission, Diagnostics, Treatment, and Prevention. Infect Dis Clin North Am. 2019; 33(4):1045-62. doi: 10.1016/j.idc.2019.08.004.

PMID: 31668190.

26.Purcell R.M. Hepatitis C virus: Genetic and biological heterogeneity. In: The twentieth anniversary of Austria symposium. Mushahwar IK, editor. Viral hepatitis. Chicago: ABBOTT; 1993. p. 47-63.

27.Selby MJ, Choo QL. Expression, identification and subcellular localization of the proteins encoded by the hepatitis C viral genome. J General Vir. 1993,74: 1103-13. PMID: 8389800.

28.Naz A, Mukry SN, Naseer I, Shamsi TS. Evaluation of efficacy of serological methods for detection of $\mathrm{HCV}$ infection in blood donors: A single centre experience. Pak J Med Sci. 2018; 34(5):1204-8. doi: 10.12669/pjms.345.15707.PMID: 30344577.

29.Fabrizi F, Dixit V, Messa P. Hepatitis $\mathrm{C}$ virus and mortality among patients on dialysis: A systematic review and meta-analysis. Clin Res Hepatol Gastroenterol. 2019; 43(3):244-54. doi: 10.1016/ j.clinre.2018.10.009. PMID: 30910601.

30.Houghton M. Han J. Structure and molecular virology. In: Zuckerman AJ, Thomas HD, editors. Viral hepatitis scientific basis and clinical management. Churchill Livingstone; 1993. p. 229-36.

31.Busch PM, Kleinman HS, Williams EA, Smith WJ. Frequency of human immunodefficiency virus (HIV) infection among contemporary anti-HIV-1 anti-HIV-1/2 supplemental test-indeterminate blood donors. Transfusion. 1996; 36: 37-44. DOI: 10.1046/ j.1537-2995.1996.36196190513.x. PMID: 8607151.

32.Reesink WH, Engelfriet PC. What are the consequences of indeterminate results in confirmatory tests for antibodies against transmissible viruses? Vox Sang. 1997; 73:97-104. PMID: 9304779

33. Holmes JR, Dinh TH, Farach N, Manders EJ, Kariuki J, Rosen DH, et al. PEPFAR HIV Casebased Surveillance Study Group. Status of HIV Case-Based Surveillance Implementation - 39 U.S. PEPFARSupported Countries, 2019. MMWR Morb Mortal Wkly Rep. 2019; 68(47):1089-95. doi: 10.15585/mmwr.mm6847a2. PMID: 31774743 .

34.Badugu P, Lippmann S. Know the New HIV Testing Guidelines? South Med J. 2019;112(4):251. doi: 10.14423/SMJ. 0000000000000954 . PMID: 30943546.

35.Korelitz JJ, Busch PM, Williams EA. Antigen testing for human immunodeficiency virus (HIV) and the magnet 
effect: will the benefit of a nem HIV test be offset by the numbers of higher-risk, testseeking donors attracted to blood centers? Transfusion. 1996; 36:203-8. DOI: 10.1046/ j.1537-2995.1996. 36396182135.x. PMID: 8604502.

36.Li L, Xu T, Yang T, Zang L, Cheng W, Lin $\mathrm{H}$, et al. Establishing a reentry procedure for human immunodeficiency virus screeningreactive donors in China. Transfusion. 2016; 56(1): 195-202. doi: 10.1111/trf.13282. PMID: 26360920.

37.Reesink WH, Engelfriet PC. What are the consequences of indeterminate results in confirmatory tests for antibodies against transmissible viruses? Vox Sang. 1997; 73: 97-104. PMID: 9304779.

38.Zaaijer IH, Van Rixel T, Van Exel-Ochlers, Cuypers T.M.H, Lelie N.P. New anti-human immunodeficiency virus immunoblot assays resolve nonspecific western blot results. Transfusion. 1997;37:193-8. DOI: 10.1046/j. 1537-2995.1997.37297203523.x. PMID: 9051095.

39.Nishimura Y, Martin MA. Of Mice, Macaques, and Men: Broadly Neutralizing Antibody Immunotherapy for HIV-1. Cell Host Microbe. 2017; 22(2): 207-16. doi: 10.1016/ j.chom.2017.07.010. PMID: 28799906.

40.Stephenson KE, Barouch DH. Broadly Neutralizing Antibodies for HIV Eradication. Curr HIV/AIDS Rep. 2016;13(1):317. DOI: 10.1007/s11904-016-0299-7. PMID: 26841901.
41.Gruell H, Klein F. Antibody-mediated prevention and treatment of HIV-1 infection. Retrovirology. 2018;15(1):73. doi: 10.1186/s12977-018-0455-9. PMID: 30445968 .

42.Morris L, Mkhize NN. Prospects for passive immunity to prevent HIV infection. PLoS Med. 2017; 14(11): e1002436. doi: 10.1371/journal.pmed. 1002436. PMID: 29136030.

43.Vitecoq D, Chevret S, Morand-Joubert L, Heshmati F, Audat F. Passive immunotherapy in AIDS: a double-blind randomized study based on transfusions of plasma rich in anti-human immuno-deficiency virus 1 antibodies vs. transfusions of seronegative plasma. Proc. Natl. Acad. Sci USA. 1995; 92: 1195-9. DOI: 10.1073/-pnas.92.4.1195. PMID: 7862660.

44.Stanković B. Povećanje incidencije oboljevanja od sifilisa u Srbiji i važeći algoritam testiranja. Naučni časopis urgentne medicine HALO 194. 2018; 24(3): 158-67.

45.Stanković B, Lazarević A, Kekuš D, Bokun R, Budimčić M, Stojanović G, i sar. Hepatitis B virus kao faktor rizika koji ugrožava zdravlje različitih kategoraija pacijenata. Svet rada. 2013; 10:(5/6): 839-46.

46.Stanković B, Lazarević A, Kekuš D, Bokun R, Budimčić M; Stojanović G. Značaj virusološkog testiranja na virus humane imunodeficijencije (HIV) kod različitih kategorija pacijenata $\mathrm{u}$ analizi prevalence i preduzimanju preventivnih mera. Svet rada. 2014; 11(3): 409-24. 
- oraginal article -

\title{
BLOOD-BORNE DISEASE MARKERS ANALYSIS, CREATING TESTING ALGORITHMS AND APPLICATION OF PREVENTIVE MEASURES
}

\author{
Bratislav STANKOVIĆ ${ }^{l}$, Ljiljana GOJKOVIĆ-BUKARICA ${ }^{l}$, Marija TRIŠOVIĆ ${ }^{l}$, Milenko BUDIMČIĆ , \\ Žana GAJIĆ , Vladan RISTIĆ
}

${ }^{1}$ Belgrade Academy for Applied Studies; Belgrade School of Applied Health Sciences, Zemun, Serbia. ${ }^{2}$

Belgrade University School of Dentistry, Laboratory, Rankeova, Belgrade, Serbia.

\begin{abstract}
Introduction/Aim The most common blood borne diseases or transfusion transmitted infections (TTI) are hepatitis B, hepatitis $\mathrm{C}$ and human immunodeficiency virus (HIV). Numerous tests are used to prove the presence of these viruses indirectly (by detecting antibody presence - ELISA and CLIA) or directly (by detecting the presence of viral genome - NAT-PCR and LCR).To present a two-year analysis of testing for blood borne disease markers in pregnant women, patients preparing for surgery procedures and people with high-risk behavior (HBs Ag, anti-HCV and anti-HIV) at the Belgrade City Institute for Public Health and adopting measures for their prevention.
\end{abstract}

Methodology During the two-year period, 11,983 pregnant women and 934 people with high-risk behavior were tested. Preliminary testing for HBs antigen, anti-HCV antibodies and anti-HIV antibodies was performed with $3^{\text {rd }}$ generation ELISA tests ("Hepanostika HBsAg Uni-Form II", "Vironostika HIV Uni-Form II Ag / Ab" ; "The bioMérieux Clinical Diagnostics," manufactured in France; "Hepanostika HCV Ultra" is manufactured by "Beijing United Biomedical Co.Ltd.", China and the other two are manufactured in France). Primarily positive blood samples were tested again with the same test (in a duplicate procedure) on a new sample which was placed in a "dry" tube with no anticoagulant 10-14 days after being primarily positive for TTI markers. Those samples were also tested with a WB "Western Blot" confirmatory test - WB ("INNO-LIA HCV Ab III"; INNO-LIPA HBV Genotyping "and" INNO-LIA HIV I / II"). "Innogenetics NV ", Belgium is the manufacturer of all three confirmatory tests. Blood samples with positive results on the confirmatory tests for TTI were accepted as positive for $\mathrm{HBs} \mathrm{Ag}$, anti-HCV or anti-HIV.

Results From 11,983 tested pregnant women, $152(1.27 \%)$ were preliminarily reactive to $\mathrm{HBsAg}, 38$ (0.32\%) were confirmed positive for HBsAg and 114 (0.95\%) were false reactive to HBsAg; 123 (1.03\%) were preliminarily reactive to anti-HCV, $35(0.29 \%)$ pregnant women were confirmed positive for anti$\mathrm{HCV}$ and $88(0.74 \%)$ were false reactive for anti-HCV; and $15(0.13 \%)$ pregnant women were preliminarily reactive to anti-HIV, $5(0.04 \%)$ pregnant women were confirmed positive for anti-HIV and 10 $(0.09 \%)$ were false reactive to anti-HIV. From 934 tested individuals with high-risk behavior $36(3.85 \%)$ were preliminarily reactive to $\mathrm{HBs} \mathrm{Ag}, 28$ (2.99\%) were confirmed positive for $\mathrm{HBsAg}$ and $8(0.86 \%)$ were false reactive to $\mathrm{HBsAg} ; 38$ (4.07\%) were preliminarily reactive to anti-HCV, 33 (3.53\%) were confirmed positive for anti-HCV and $5(0.54 \%)$ false reactive to anti-HCV and $10(1.07 \%)$ were preliminarily reactive to anti-HIV, $9(0.96 \%)$ were confirmed anti-HIV positive and $1(0.11 \%)$ was false reactive to anti-HIV.

Conclusion The results of our study showed a higher prevalence of HBsAg, anti-HCV and anti-HIV in people with high-risk behavior than in pregnant women. There are more false reactive results in pregnant women than in people with high-risk behavior. Preventive measures would include broader education on ways blood borne diseases are transmitted, testing blood and blood products with the latest generation of tests and correct execution of medical interventions with special attention on principles of asepsis and antisepsis.

Key words blood borne disease markers; hepatitis B virus (HBV); hepatitis C virus (HCV); human immunodeficiency virus (HIV); preventive measures. 